\title{
Les carrières de pierre de Caromb
}

Philippe Bernardi, Jean-Marc Mignon et Philippe Bromblet

\section{OpenEdition \\ Journals}

Édition électronique

URL : http://journals.openedition.org/adlfi/6593

ISSN : 2114-0502

Éditeur

Ministère de la culture

Référence électronique

Philippe Bernardi, Jean-Marc Mignon et Philippe Bromblet, "Les carrières de pierre de Caromb ", ADLFI. Archéologie de la France - Informations [En ligne], Provence-Alpes-Côte d'Azur, mis en ligne le 01 mars 2007, consulté le 03 mai 2019. URL : http://journals.openedition.org/adlfi/6593

Ce document a été généré automatiquement le 3 mai 2019.

(c) Ministère de la Culture et de la Communication, CNRS 


\title{
Les carrières de pierre de Caromb
}

\author{
Philippe Bernardi, Jean-Marc Mignon et Philippe Bromblet
}

Identifiant de l'opération archéologique : 8265

Date de l'opération : 2007 (PC)

Inventeur(s) : Bernardi Philippe (CNRS) ; Mignon Jean-Marc (SAR) ; Bromblet

Philippe (COL)

1 Le projet de ce PCR est de suivre l'évolution de la production des carrières de Caromb sur la longue durée (de l'Antiquité à l'époque contemporaine), par l'apport conjoint d'études archéologiques, archivistiques et géologiques. Il entend cerner une exploitation importante par sa durée et par son rayonnement, à travers une appréhension plus fine des qualités de cette pierre comme de ses emplois et de sa commercialisation.

2 La combinaison d'une approche historique avec une thématique de conservation et de restauration permettra, à terme, de mieux appréhender les altérations du matériau pour y remédier ou rechercher, parmi les roches actuellement en exploitation, un substitut possible.

\section{Volet archéologique}

3 L'enquête archéologique a consisté, au cours de cette première année, en un repérage des traces d'extraction sur les parcelles du lieu-dit Les Peyrières appartenant à la commune de Caromb. Un relevé topographique, commandé dans cette optique à un cabinet de géomètre-expert, nous a permis de positionner précisément une série de fronts rocheux taillés dont nous avons effectué le relevé photographique (Fig. ${ }^{\circ} 1$ : Vue d'une partie des fronts de taille dégagés) et graphique. Les fronts rocheux semblent globalement parallèles et de direction est-ouest. En partie basse du site, il apparait nettement que les fronts rocheux correspondent à une réouverture à l'exploitation de zones anciennement utilisées puis abandonnées. La surface rocheuse est, en effet, recouverte d'un épais 
remblai constitué de déchets de taille mêlés à des éléments assimilables à des blocs d'architecture abandonnés en cours d'exécution et, dans plusieurs cas, cette couche de remblai a été entaillée lors de la réalisation des fronts (Fig. $n^{\circ} 2$ : Vue de détail du front est de la zone).

4 La surface du banc rocheux conserve, en outre, les traces nettes d'une exploitation ancienne. Parmi les éléments recueillis au cours de ces premiers relevés et repérages, quelques-uns concourent à proposer une exploitation de la carrière dès l'Antiquité. Si la présence d'un fragment d'amphore gauloise ( ${ }^{e r}-{ }^{-I I I}{ }^{e} s$. apr. J.-C.) dans les déblais ne suffit pas à caractériser une exploitation antique, la présence de traces d'escoude à deux dents paraît attester avec plus de solidité une telle datation.

\section{L'étude des textes}

5 À ce jour, le corpus réuni se compose de plus de deux cent soixante-dix mentions relatives à la pierre, aux carriers ou aux carrières de Caromb. Nous avons pu retrouver l'identité de soixante et un carriers, entre 1338 et 1883, ce qui permet d'entrevoir trois phénomènes majeurs: le caractère presque familial du métier; l'importance des associations; le rôle probable des tailleurs de pierre de Caromb dans la diffusion ou la mise en valeur du matériau.

Au-delà du quartier des Peyrières où des exploitations sont attestées du XIV ${ }^{e} s$. au XIX ${ }^{e}$ s., d'autres zones d'extraction se font jour: dans les quartiers voisins de la Tuilière, sur le territoire du Barroux, ou des Nauds, directement au sud des Peyrières.

7 Cette enquête confirme que la pierre de Caromb est souvent employée en raison de sa relative imperméabilité mais souligne également la production de blocs de très grandes dimensions (jusqu'à $2 \mathrm{~m}$ voire $4-5 \mathrm{~m}$ selon un auteur du XIX $\mathrm{s}$.).

La multiplication de mentions d'usage conjoint de pierres d'origines différentes sur un même chantier amène à s'interroger sur ces «alternatives » à la pierre de Caromb. Leur analyse fine devrait contribuer à mieux cerner les qualités reconnues à la pierre de Caromb et aider à la replacer dans un contexte de production régional.

9 L'enquête a permis, en outre, d'établir des fiches sur les différents sites d'emploi de ce matériau pour guider les futures campagnes de prélèvements.

\section{L'étude géologique}

10 Nous avons, dans ce premier temps, engagé l'étude comparative des propriétés (capillarité, porosité, vitesse de séchage, vitesse du son, résistance mécanique, cinétique d'évaporation) de la pierre de Caromb et de la pierre de Crillon (encore en exploitation) utilisée en remplacement de la pierre de Caromb dans les restaurations des monuments régionaux.

11 Une série de carottages a été effectuée dans les différents faciès observables à Crillon afin de nous permettre de caractériser la roche. Les sections polies et les lames minces nécessaires à ces analyses sont actuellement en cours de réalisation au CICRP.

Parallèlement, nous poursuivons l'analyse des échantillons prélevés à Caromb avec, notamment, l'étude du mécanisme d'altération de cette pierre. Nous menons, dans cette optique, une série de tests de manière plus ou moins expérimentale: analyses 
minéralogiques par DRX qualitatives globales et de la fraction argileuse; estimation de cette dernière et mise en évidence de phases argileuses de type gonflant dans celle-ci ; mesure de dilatation hygrique.

BERNARDI Philippe, MIGNON Jean-Marc et BROMBLET Philippe

14 Participent également à ce PCR : Lise Leroux (LRMH), Jean-Marc Vallet (CICRP) et Élydia Barret (LAMM).

\section{ANNEXES}

Fig. $\mathrm{n}^{\circ} 1$ : Vue d'une partie des fronts de taille dégagés

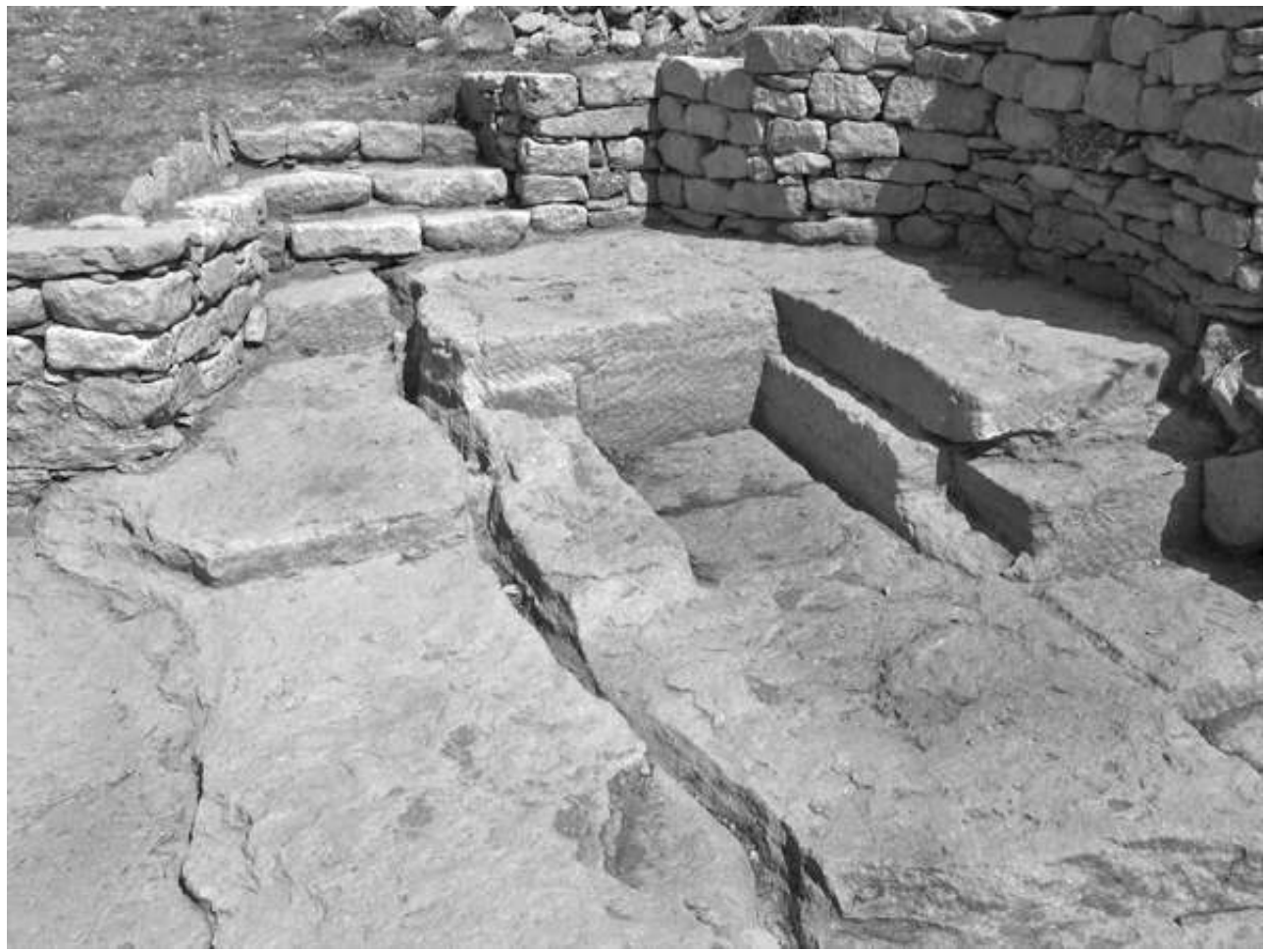

Auteur(s) : Bernardi, Philippe. Crédits : ADLFI (2007) 
Fig. $n^{\circ} 2$ : Vue de détail du front est de la zone

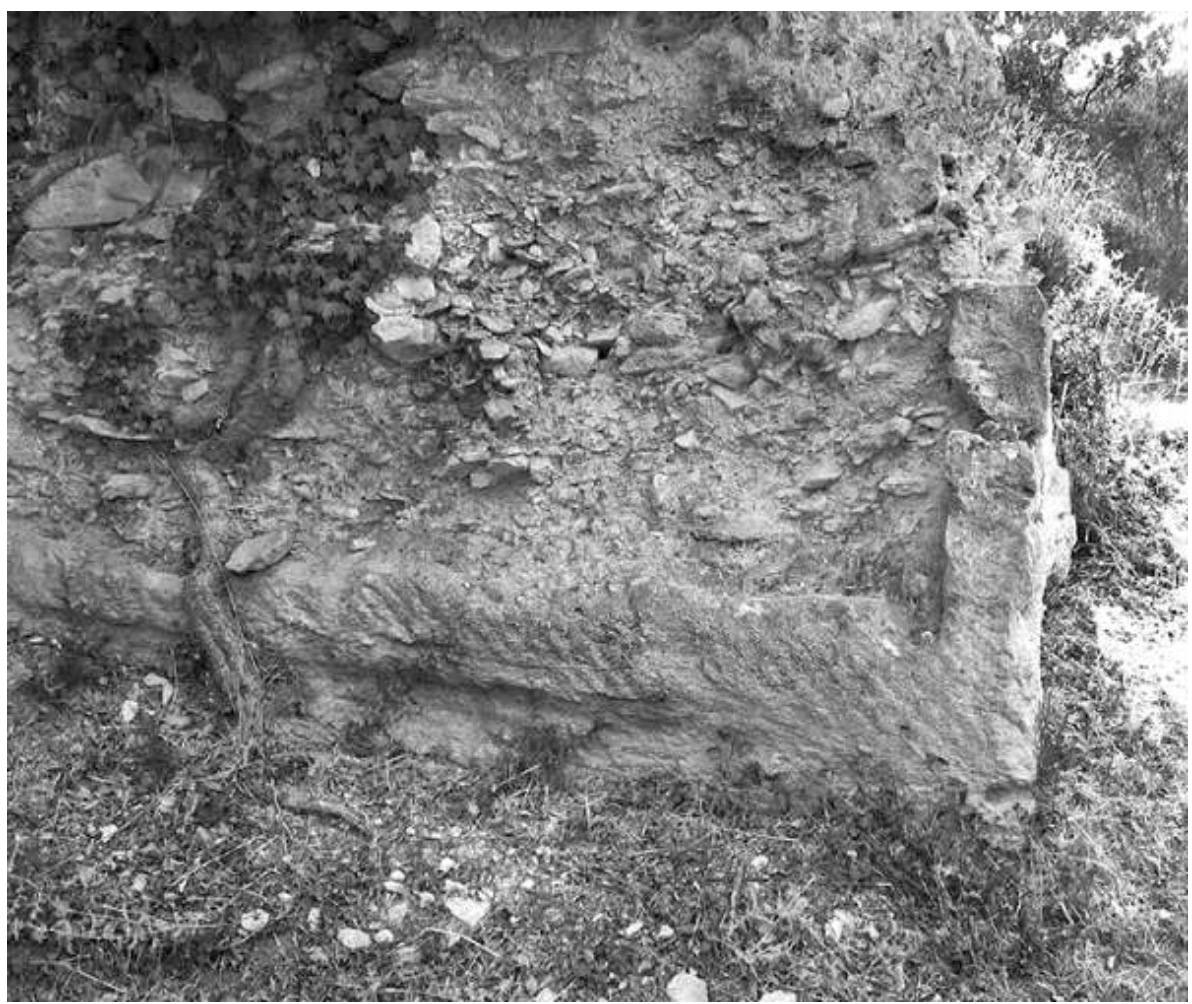

Auteur(s) : Bernardi, Philippe. Crédits : ADLFI (2007)

INDEX

Index chronologique : Antiquité romaine, ép. contemporaine, Ier siècle apr. J.-C., IIIe siècle apr. J.-C., Moyen Âge, XIVe siècle apr. J.-C., XIXe siècle apr. J.-C.

operation Projet collectif de recherche (PCR)

Index géographique : Provence-Alpes-Côte d'Azur, Vaucluse (84), Caromb

\title{
AUTEURS
}

\author{
PHILIPPE BERNARDI \\ CNRS
}

JEAN-MARC MIGNON

SAR

PHILIPPE BROMBLET

COL 